educational goals. Handbook I: Cognitive domain. New York: David McKay Company.

20. MGI-Skill-Shift-Automation-and-future-of-the-workforce (2018). https://www.mckinsey.com/ /media/McKinsey/Industries/Public\%20and\%2 0Social\%20Sector/Our\%20Insights/Skill\%20shift\%20Automation\%20and\% 20the $\% 20$ future $\% 20 \mathrm{of} \% 20$ the $\% 20$ workforce/MGI-Skill-Shift-Automationand-future-of-the-workforce-In-brief-May-2018.pdf (accessed 10.09.20).

DOI https://doi.org/10.30525/978-9934-588-80-8-2.7

\title{
ОРГАНІЗАЦІЯ САМОСТІЙНОЇ ТА ІНДИВІДУАЛЬНОЇ РОБОТИ УЧНІВ В УМОВАХ ДИСТАНЦЙНОЇ ОСВІТИ
}

\author{
Задоріна О. М. \\ кандидат педагогічних наук, \\ стариий викладач кафедри методики викладання і змісту освіти \\ КЗ «Одеська академія неперервної освіти Одеської обласної ради»
}

Задорін В. В.

викладач інформатики

Одеський фаховий технічний коледж

Одеської національної академії харчових технологій

м. Одеса, Україна

Гуманізація освіти передбачає перегляд, переоцінку всіх компонентів методичної системи навчання, створення максимально сприятливих умов для розкриття і розвитку здібностей особи, що здобуває знання. Один із провідних напрямків гуманізації - впровадження особистісно зорієнтованого навчання, мета якого не тільки навчати й виховувати учня, а й формувати в ньому особистість. Такий підхід до навчального процесу передбачає індивідуалізацію, а отже, й диференціацію навчання, ефективним засобом якої за певної умови організації $\epsilon$ самостійна робота.

Одне з головних завдань сучасної освіти - навчити учнів самостійно працювати, оскільки темпи надходження наукової інформації надзвичайно зросли і практично кожній людині, яка хоче мати роботу та продуктивно працювати, необхідно увесь час поновлювати свої знання, а то й переучуватись, а це можливо лише за наявності сформованих умінь і навичок самостійної роботи. 
Як показала практика раптового впровадження дистанційного навчання навесні 2020 року, переважна більшість здобувачів освіти (як учнів загальноосвітніх шкіл, так і студентів вищих навчальних закладів) мають слабкі та недостатні навички самостійної діяльності. Вони легко орієнтуються у потоці інформації, яку отримують 3 різноманітних джерел, проте не можуть структурувати та проаналізувати навчальний матеріал, встановити логічні взаємозв'язки, виокремити найголовніше у тому, що необхідно опанувати. Тож навчати вчитися самостійно необхідно тоді, коли $є$ живий взаємозв'язок викладача та студента, вчителя та учня.

Під час організації самостійної роботи основною метою є самостійне вивчення матеріалу. Найвпливовішим критерієм для вибору методів навчання $\epsilon$ показники підготовленості учнів до такої діяльності: рівень сформованості пізнавальної самостійності, предметних та загальнонавчальних знань, навичок і вмінь. Організовуючи самостійну роботу, вчитель має стежити за тим, щоб учень був внутрішньо переконаний у необхідності їі виконання. Це викликано його особистими потребами: пізнати нове, перевірити свої знання, виявити самостійність, навчитися працювати самостійно. Досить важливо стимулювати i вмотивувати позитивне ставлення школярів до виконання самостійної роботи.

Говорити про самостійну роботу як про діяльність учня або студента можна лише тоді, коли в нього $є$ відповідна система мотивів. Учень повинен чітко усвідомлювати, чому він виконує ту чи іншу самостійну роботу. Можливі такі мотиви:

- оволодіти знаннями;

- перевірити свої вміння та навички у розв'язуванні тих або інших задач;

- оцінити рівень знань із певної теми.

Перед виконанням самостійної роботи слід завжди повідомляти іiї мету, звертати увагу учня на ії користь особисто для нього.

Велику зацікавленість викликають в учнів творчі роботи, які потребують високого рівня самостійності. Виконуючи завдання, учні відкривають нове в темі, яку вивчали на попередніх заняттях. Наприклад, це завдання, які спрямовані на пошук інших способів розв'язання задач.

Працюючи самостійно, учні, як правило, глибше вдумуються у зміст матеріалу, що опрацьовується, краще зосереджують свою увагу. Тому знання, вміння і навички, набуті в результаті самостійної роботи, виховують в учнів наполегливість, увагу, витримку.

Одним із видів роботи в класі є самостійне вивчення теорії за підручником або 3 різноманітних Internet-джерел. Самостійно 32 
опрацьовувати теоретичний матеріал учням можна пропонувати 2-3 рази в семестр. Основна мета таких завдань - навчити учнів читати текст, що пропонується до вивчення. Якщо говорити, наприклад про математичний текст, то його особливості, по-перше, в тому, що він містить багато математичних, понять, термінів, формул, символів. Коли учень не знає якийсь із термінів чи символів, то він не зможе повністю зрозуміти текст. По-друге, у тексті є різні схеми та рисунки, що тісно 3 ним пов'язані. На них треба дивитися паралельно з читанням тексту, читати доводиться не абзацами, а реченнями. По-третє, наявність різних шрифтів, якими виділяють означення, теореми, примітки. Почетверте, стиль викладу матеріалу - чіткість, строгість, лаконічність.

Самостійна навчально-пізнавальна діяльність учнів ефективна, якщо вона:

- допомагає учням засвоювати матеріал глибоко і міцно;

- розвиває їхні пізнавальні здібності;

- формує вміння самостійно розширювати й поглиблювати знання та застосувати їх на практиці;

- відповідає основним принципам дидактики: доступності, систематичності, зв'язку теорії з практикою, свідомості, творчої активності, навчанню на високому рівні.

Завдання, що входять до системи самостійної діяльності, мають бути різними за дидактичною метою та змістом. Послідовність виконання домашніх і класних самостійних робіт повинна бути такою, щоб виконання одних робіт логічно випливало 3 попередніх $\mathrm{i}$ підготовлювало учнів до виконання наступних.

Самостійна робота повинна носити цілеспрямований характер, що досягається чітким визначенням ії мети; недооцінення цієї вимоги призводить до того, що учні або неправильно виконують завдання, або вимагають від учителя додаткових пояснень, через що відбувається нераціональне використання часу.

Спочатку в учнів необхідно сформувати елементарні навички самостійної діяльності як під час роботи з підручником, так і під час виконання практичних завдань, рисунків, простих вимірів, розв'язування задач. Цьому повинна передувати наочна демонстрація вчителем цих видів роботи, яка супроводжується чіткими поясненнями i записами на дошці. Для самостійної роботи учням необхідно пропонувати завдання, що розв'язуються за готовими алгоритмами, а також такі, які вимагають їх створення.

Необхідно враховувати те, що різним учням потрібна різна кількість, часу для засвоєння одних і тих самих знань, умінь та навичок. I, чи не найголовніше: завдання мають бути цікавими для учнів. 
Викладач визначає мету, зміст, обсяг, методи і види самостійної роботи. Ефективність самостійної роботи збільшується, якщо вона $€$ однією зі складових навчального процесу і проводиться планомірно та систематично.

Самостійна робота займає виняткове місце у сучасній школі, тому що учень здобуває знання тільки в процесі особистої самостійної навчальної роботи. Дидактичне правило «Вчити дітей вчитися» ніколи не було таке актуальне як зараз. Уміння керувати своєю діяльністю виступає в якості необхідної умови в житті людини і в ії трудовій діяльності. Застосування сучасних технологій на уроках і в позаурочній діяльності розширює можливості творчості як вчителів, так і учнів, підвищує інтерес до предмету, стимулює засвоєння учнями нових знань, що, в результаті, веде до інтенсифікації процесу навчання. Знання засвоюються учнем завдяки його власній діяльності, яка організована і здійснюється під керівництвом вчителя так, щоб учень мав перед собою реальні орієнтири, що дозволяють йому здійснювати всі дії правильно і одночасно контролювати себе.

Останнім часом школа поставлена в ситуацію необхідності введення істотних змін у систему навчання i виховання учнів. Впровадження сучасних педагогічних технологій в практику роботи дозволить досягти цієї мети.

\section{Література:}

1. Вишневський О. Теоретичні основи сучасної української педагогіки. Самостійна діяльність учнів. -Дрогобич: Коло, 2006. - 326 с.

2. Освітні технології: Навчально-методичний посібник, О.М. Пехота та ін., - К. : А. С. К, 2004. - 256 с.

3. Пометун О. Сучасний урок. Інтерактивні технології навчання. К. : Видавництво А.С. К., 2004, - 192 с.

4. Рибак Т.А. Технологія уроків узагальнення і систематизації знань, умінь і навичок у процесі викладання математики / Т.А. Рибак // Математика в шк. України. - 2005. - № 1. - С. 2-5.

5. Інтерактивні технології на уроках математики / уклад. I.С. Маркова - Х.: Основа, 2009, - 126 с. 